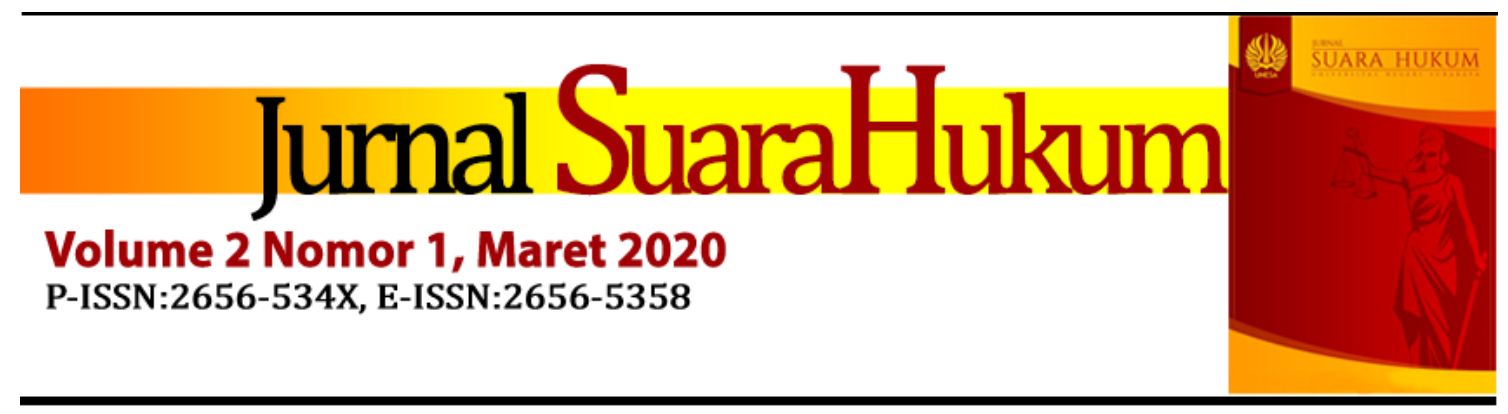

\title{
Prinsip Kehati-hatian bagi Bank Selaku Kustodian di Pasar Modal Indonesia
}

\author{
Rezandha Hutagulung \\ Fakultas Hukum, Universitas Indonesia, Depok, Indonesia, \\ rezandhadtr@gmail.com
}

\begin{abstract}
This journal aims to find out how to apply the precautionary principle of a bank as a custodian bank in Indonesian capital market. Whereas with the enactment of Law Number 1995 concerning the Capital Market, it is deemed necessary to enact a Bapepam Decision regarding the Custodian Bank's Report. In the context of carrying out Indonesia's economic development, of course the challenges are not insignificant for financial institutions, one of which is in banking institutions. The role of banking institutions that carry out the main task as a vehicle that can collect and distribute funds effectively and efficiently, requires continuous improvement in order to be able to have a comparative advantage. This journal is how about the application of the precautionary principle in the capital market in Indonesia. Custodian Bank is a commercial bank that has obtained the approval of the Financial Services Authority (OJK) to carry out business activities as a custodian. The object of legal research is legal norms, which have the aim of examining whether or not a regulation is appropriated and applied.
\end{abstract}

Keywords: Custodian Bank, Capital Market, Prudential Principle

\section{Pendahuluan}

Menurut Sunaryati Hartono, pada dasarnya terdapat 4 (empat) fungsi hukum dalam pembangunan nasional, yakni: ${ }^{1}$

1. Hukum sebagai pemeliharan ketertiban dan keamanan;

2. Hukum sebagai sarana pembangunan;

3. Hukum sebagai sarana penegak keadilan; dan

\footnotetext{
1 Sunaryati Hartono, Politik Hukum Menuju Satu Sistem Hukum Nasional, PT Alumni, Bandung, 2000, hlm. 53
} 
4. Hukum sebagai sarana pendidikan masyarakat.

Di sebuah negara yang kegiatan pemerintahannya telah tertata dengan tertib dan teratur, pembangunan ekonomi nasional dilaksanakan berdasarkan rencana yang telah disusun secara lengkap (comprehensive) dan terprogram dengan baik. Pembangunan ekonomi dimaksud dilaksanakan secara berkesinambungan dan hasil yang dicapai pada satu tahapan pembangunan akan dijadikan sebagai acuan untuk menentukan tahapan-tahapan pembangunan selanjutnya. ${ }^{2}$ Pembangunan ekonomi yang dilaksanakan pemerintah akan berbeda di antara satu negara dengan negara lainnya. Makna pembangunan ekonomi di negara maju adalah perjuangan untuk menguasai potensi ekonomi, kesejahteraan masyarakat, dan perjuangan untuk mempertahankan kepentingan masa kini dan masa depan bangsanya. ${ }^{3}$

Di pihak lain, makna pembangunan ekonomi bagi negara berkembang selain perjuangan untuk meningkatkan pertumbuhan ekonomi dan meningkatkan kesejahteraan masyarakat, juga merupakan perjuangan untuk melawan tekanan ekonomi dari negara-negara maju. ${ }^{4}$ Negara berkembang harus segera memacu pembangunan ekonominya sedemikian rupa agar dapat mengejar ketinggalan dari pembangunan ekonomi di negara-negara maju. ${ }^{5}$ Tidak jarang terjadi bahwa untuk memperkecil jurang pemisah dengan negara-negara maju, negara-negara berkembang melaksanakan rangkaian proses pembangunan ekonomi secara serentak yang oleh negara maju dilaksanakan secara bertahap dan terencana. ${ }^{6}$

Dalam melaksanakan rangkaian proses pembangunan ekonomi menimbulkan tantangan yang tidak sedikit bagi lembaga-lembaga keuangan di Indonesia, salah satunya adalah dalam lembaga perbankan. Peran strategis

\footnotetext{
${ }^{2}$ Jonker Sihombing, Investasi Asing Melalui Surat Utang Negara di Pasar Modal, PT Alumni, Bandung, 2013, hlm. 48

${ }^{3}$ Lili Rasjidi \& IB. Wyasa Putra, Hukum sebagai Suatu Sistem, cetakan ke-2, Penerbit Mandar Maju, Bandung, 2003, hlm. 170

${ }^{4}$ Ibid.

5Jonker Sihombing, op.cit., hlm. 49

${ }^{6}$ Satjipto Rahardjo, Hukum dan Masyarakat, Penerbit Angkasa, Bandung, 1980, hlm. 132
} 
lembaga perbankan yang mengemban tugas utama sebagai wahana yang dapat menghimpun dan menyalurkan dana secara efektif dan efisien, memerlukan penyempurnaan yang terus-menerus agar mampu memiliki keunggulan komparatif. Lembaga perbankan mempunyai fungsi dan tanggung jawab yang sangat besar. ${ }^{7}$

Sejak Indonesia merdeka, Pemerintah Republik Indonesia telah menyusun 3 (tiga) undang-undang yang mengatur tentang Perbankan, yaitu UndangUndang Nomor 14 Tahun 1967 tentang Pokok-Pokok Perbankan,UndangUndang Nomor 7 Tahun 1992 tentang Perbankan, dan Undang- Undang Nomor 10 Tahun 1998 tentang Perubahan Atas Undang-Undang Nomor 7 Tahun 1992 tentang Perbankan. ${ }^{8}$ Selain peraturan dalam bentuk undang-undang, juga telah dikeluarkan berbagai paket kebijakan. ${ }^{9}$ Pengaturan perbankan di Indonesia memiliki beberapa fungsi utama, ${ }^{10}$ yakni: ${ }^{11}$

Pertama, untuk tujuan moneter, pengaturan perbankan diarahkan untuk tujuan moneter dan ditujukan untuk mendorong stabilitas moneter di Indonesia. Hal ini mengingat masih dominannya perbankan sebagai sumber pembiayaan investasi. Kedua, untuk tujuan pengawasan terhadap industry perbankan. Pengaturan perbankan untuk tujuan pengawasan adalah dalam rangka menjaga keamanan dan kesehatan bank maupun kesahatan system keuangan secara keseluruhan, melindungi nasabah, dan menjaga stabilitas pasar uang, serta mendorong sistem perbankan yang efisiendan kompetitif. Ketiga, untuk tujuan pembangunan. Pengaturan perbankan untuk tujuan pencapaian program pembangunan diarahkan agar perbankan nasional dapat mengatasi masalahmasalah ekonomi pada masa pembangunan.

\footnotetext{
7 Yoyo Sudaryo, Aditya Yudanegara, Investasi Bank dan Lembaga Keuangan, CV. ANDI OFFSET, Yogyakarta, 2017, hlm. 37

8 Ibid., hlm. 41

9 Edward W. Reed, Edward K. Gill, Commercial Bank. Penerjemah St. Dianjung. Prentice, Hall, Inc.Bumi Aksara, Jakarta, 1995, hlm. 29.

${ }^{10}$ Heri Soepraptomo, Analisis Ekonomi terhadap Hukum Perbankan. Makalah pada Pertemuan Ilmiah tentang Analisis Ekonomi terhadap Hukum dalam Menyongsong Era Globalisasi. BPHN Departemen Kehakiman, Jakarta, 10-11 Desember 1996. hlm. 7

11 Yoyo Sudaryo, Aditya Yudanegara, op.cit., hlm. 42
} 
Kemajuan yang dialami lembaga perbankan dapat ditingkatkan secara berkelanjutan dan memberikan manfaat yang sebesar-besarnya bagi pelaksanaan pembangunan nasional, maka segala potensi, inisiatif dan kreasi masyarakat harus dapat dikerahkan dan dikembangkan menjadi suatu kekuatan riil bagi peningkatan kemakmuran rakyat. ${ }^{12}$

Mengenai kegiatan bank telah diatur dalam Undang-Undang Perbankan, seperti menghimpun dana dari masyarakat dalam bentuk simpanan berupa giro, deposito berjangka, sertifikat deposito, tabungan, memberikan kredit, memberi surat pengakuan utang, memindahkan uang, menempatkan serta meminjam dana, melakukan kegiatan penitipan, dan lain-lain selama tidak melanggar halhal yang telah diatur dalam peraturan perundang-undangan. ${ }^{13}$

Jika diterjemahkan ke dalam bentuk-bentuk tanggung jawab, maka bentukbentuk tanggung jawab perbankan adalah: ${ }^{14}$

1. Tanggung jawab prudential (bank harus sehat).

2. Tanggung jawab komersial (bank harus untung).

3. Tanggung jawab finansial (bank harus transparan).

4. Tanggung jawab sosial (kemampuan mengakomodir harapan stakeholder secara adil).

Menurut Heru Soepraptomo, sebagai agen dari pembangunan, bank diharapkan dapat memberikan kontribusi pada usaha meningkatkan tabungan nasional, menumbuhkan kegiatan usaha, dan meningkatkan alokasi sumbersumber perekonomian. ${ }^{15}$ Dalam dunia perbankan dikenal Bank Kustodian yang mana berdasarkan Undang-Undang No. 8 Tahun 1995 tentang Pasar Modal merupakan pihak yang memberikan jasa penitipan efek dan harta lain yang berkaitan dengan efek serta jasa lain, termasuk menerima dividen, bunga, dan hak-hak lain, menyelesaikan transaksi efek, dan mewakili pemegang rekening

\footnotetext{
12 Bachsan Mustafa, Sistem Hukum Indonesia Terpadu, Citra Aditya Bakti, Bandung, 2003, hlm. 12.

${ }^{13}$ Lihat Pasal 6 Undang-Undang No. 7 Tahun 1992 jo. Undang-Undang No. 10 Tahun 1998 tentang Perbankan

14 Yoyo Sudaryo, Aditya Yudanegara, op.cit., hlm. 37

${ }^{15}$ Heru Soepraptomo, op.cit., hlm. 1
} 
yang menjadi nasabahnya. Berdasarkan Pasal 43 ayat (1) Undang-Undang Pasar Modal dijelaskan bahwa pihakpihak yang dapat menyelenggarakan kegiatan usaha sebagai custodian adalah Kustodian Sentral Efek Indonesia (KSEI), perusahaan efek atau Bank Umum yang telah mendapatkan persetujuan dari Badan Pengawas Pasar Modal (BAPEPAM). Kemudian, dalam Pasal 44 ayat (1) juga disebutkan bahwa Kustodian yang menyelenggarakan kegiatan penitipan bertanggungjawab untuk menyimpan efek milik pemegang rekening dan memenuhi kewajiban lain sesuai dengan kontrak antara kustodian dan pemegang rekening yang dimaksud.

Jika ditinjau dari pengertian Kustodian, maka dapat disimpulkan bahwa Kustodian memegang peran yang cukup penting dalam alur transaksi pasar modal. Dalam menjalankan menjalankan perannya sebagai Kustodian, bank tentu saja tetap harus memegang asas-asas dan prinsip-prinsipnya sebagai wadah menyimpanan aset dari para nasabahnya yaitu prinsip kepercayaan (fiduciary relation principle), prinsip kehati-hatian (prudential principle), prinsip kerahasiaan (secrecy principle), dan prinsip mengenal nasabah (know how costumer principle). ${ }^{16}$ Prinsip kehati-hatian (prudential principle) merupakan sebuah prinsip yang menegaskan bahwa bank dalam menjalankan kegiatan usaha, baik dalam penghimpunan, ataupun terutama dalam penyaluran dana kepada masyarakat harus sangat berhati-hati. Tujuan dilakukannya prinsip kehati-hatian tidak lain adalah agar bank selalu dalam keadaan sehat atau bank agar selalu dalam keadaan likuid dan solvent. Dengan diberlakukannya prinsip kehati-hatian diharapkan kadar kepercayaan masyarakat terhadap perbankan tetap tinggi, sehingga masyarakat bersedia dan tidak ragu ragu untuk menyimpan dananya di bank. ${ }^{17}$

Bank Kustodian merupakan bagian dari Pasar Modal, yang mana Pasar Modal disusun dengan menimbang bahwa tujuan pembangunan nasional

\footnotetext{
16 Yoyo Sudaryo, Aditya Yudanegara, op.cit., hlm. 39

17 Zulfi Diane Zaini, Independensi Bank Indonesia dan Penyelesaian Bank Bermasalah, Keni

Media, Bandung, 2012, hlm. 57
} 
adalah terciptanya suatu masyarakat adil dan makmur berdasarkan Pancasila dan Undang-Undang Dasar 1945. Pasar Modal mempunyai peran yang strategis dalam pembangunan nasional sebagai salah satu sumber pembiayaan bagi dunia usaha dan wahana investasi bagi masyarakat. Bahwa agar Pasar Modal dapat berkembang dibutuhkan adanya landasan hukum yang kukuh untuk lebih menjamin kepastian hukum pihak-pihak yang melakukan kegiatan di Pasar Modal serta melindungi kepentingan masyarakat pemodal dari praktik yang merugikan. Berdasarkan hal-hal tersebut, maka dipandang perlu membentuk Undang-Undang tentang Pasar Modal.

Menurut Jusuf Anwar, banyak Negara yang menyadari bahwa pasar modal merupakan suatu sarana yang bernilai positif dan produktif guna mendorong perekonomian negaranya masing-masing. Negara yang menganut paham sosialis-pun, seperti RRC, dalam kehidupan perekonomiannya sudah mengarah pada praktik yang umum terdapat di Negara kapitalis. Dewasa ini pengembangan pasar modal RRC dapat diperhatikan terjadi di bagian selatan seperti Shanghai dan Zhen-zhen. Di samping itu, pasar modal merupakan alternatif baru bagi para pemodal untuk melakukan investasi. Dengan berbagai alternatif investasi yang telah ada seperti perbankan, properti, dan komoditi para pemodal dapat melakukan pilihan investasi secara tepat serta memberikan manfaat terbaik. ${ }^{18}$ Nilai positif lainnya dari lembaga pasar modal adalah menyediakan sarana diversifikasi risiko, baik untuk emiten maupun untuk pemodal. Ada pula fungsi lainnya, antara lain fungsi pasar modal dalam mekanisme alokasi modal dan pemantauan korporasi, serta sebagai sarana bagi pemerintah untuk melaksanakan ekonomi pasar di samping memanfaatkan baik kebijakan fiskal maupun moneter. ${ }^{19}$

\footnotetext{
${ }^{18}$ Jusuf Anwar, Pasar Modal Sebagai Sarana Pembiayaan dan Investasi, PT Alumni Bandung, Bandung, 2010, hlm. 3

${ }^{19}$ Robert Pardy, Institutional Reform in Emerging Securities Markets, The World Bank, Washington DC-USA, hal. 2, Robert Pardy selanjutnya mengatakan bahwa "the basing building block among other are legal and regulatory and institutional infrastructure capable of supporting efficient operation of the securities market". Disebutkan pula bahwa "Monetary and Fiscal Environment" merupakan hal yang penting.
} 
Dalam kegiatan investasi, secara umum dikenal adanya prinsip bahwa semakin tinggi tingkat keuntungan yang diharapkan maka semakin tinggi pula tingkat risiko yang kemungkinan dihadapi, dan sebaliknya semakin rendah tingkat keuntungan yang diharapkan maka semakin rendah pula kemungkinan risiko yang dihadapi (high risk high return and low risk low return). Dalam hubungan ini, yang penting untuk diperhatikan dalam mengembangkan pasar modal adalah prinsip-prinsip keterbukaan dan perlindungan para investor. Untuk mengembangkan pasar modal di suatu Negara, prinsip tersebut merupakan prinsip baku yang berlaku universal dan hal itu harus dijamin melalui sistem hukum yang baik, kelembagaan yang jelas fungsi dan tugasnya masing-masing, serta pelaksanaan penegakan hukum yang tegas dan adil. Persyaratan keterbukaan perusahaan menjamin baik tersedianya informasi keuangan bagi publik maupun bagi keperluan antara perusahaan. ${ }^{20}$

Melihat bahwa prinsip keterbukaan yang dinilai sebagai prinsip baku yang berlaku universal perlu diterapkan prinsip kehati-hatian dalam pelaksanaan kegiatan Kustodian. Pengaturan mengenai prinsip kehati-hatian dalam hukum perbankan, baik Bank Umum maupun Bank Kustodian, dikategorikan sebagai “ $a$ seamless web" yang bertujuan untuk mencapai suatu sistem perbankan yang sehat dan efisien. ${ }^{21}$ Prudential Regulation merupakan aturan main yang merupakan kerangka hukum, sosial dan politik. Dalam konsep prudential regulation ukuran moral sangat ditentukan oleh akibat tindakan yang dilakukan oleh pelaku bisnis bank dalam mengelola bisnisnya untuk mencapai suatu bank yang sehat, efisien tangguh bersaing dan dapat berperan mendukung pembangunan ekonomi nasional. ${ }^{22}$

Kegiatan Bank Kustodian sebagaimana tercantum dalam Petunjuk Pelaksanaan Peraturan Pasar Modal, Bank Kustodian wajib melaksanakan

\footnotetext{
20 Terry M. Chuppe dan Michael Atkins, Regulation of Securities Markets Some Rescue Trend and Their Implications for Emerging Markets, Policy Research Working Paper, The World Bank, Washington DC-USA, 1992, hlm. 4

${ }^{21}$ Ricardo Siregar, Dialogia Iuridica: Mitigasi Risiko Kredit Dalam Penyaluran Kredit

Perbankan, November 2010, Vol. 2 No. 1, hlm. 115

22 Ibid.
} 
Penitipan Kolektif dan penyimpanan atas seluruh dokumen berharga berkaitan dengan Kontrak Investasi Kolektif Efek Beragun Aset (KIKEBA), melaksanakan penyimpanan dana yang merupakan aset keuangan dalam portofolio KIK-EBA, menyerahkan dan menerima aset keuangan untuk kepentingan KIK-EBA, melakukan pembayaran semua transaksi atas perintah Manajer Investasi yang berkaitan dengan KIK-EBA, mendaftarkan atas nama Bank Kustodian aset keuangan dalam portofolio KIK-EBA sebagai wakil dari pemegang Efek Beragun Aset, melaksanakan pembukuan atas hal-hal yang berkaitan dengan KIK-EBA, membuat dan menyimpan daftar pemegang Efek Beragun Aset dan mencatat perpindahan kepemilikan Efek Beragun Aset atau menunjuk Biro Administrasi Efek untuk melakukan jasa tersebut berdasarkan persetujuan dari Manajer Investasi, memisahkan aset keuangan KIK-EBA dari aset keuangan Bank Kustodian dan atau kekayaan nasabah lain dari Bank Kustodian, melaporkan secara tertulis kepada Bapepam apabila Manajer Investasi melakukan kegiatan yang dapat merugikan pemegang Efek Beragun Aset selambat-lambatnya akhir hari kerja berikutnya, dan melaksanakan tugas lain yang berkaitan dengan portofolio KIK-EBA sebagaimana ditentukan dalam Kontrak Investasi Kolektif. ${ }^{23}$

\section{Rumusan Masalah}

Bagaimana penerapan prinsip kehati-hatian bagi bank selaku Kustodian di Pasar Modal Indonesia?

\section{Metode Penelitian}

Objek dari penelitian hukum adalah norma hukum, yang memiliki tujuan untuk menguji sesuai atau tidaknya suatu peraturan dan penerapannya agar nilai kemanfaatan, kepastian, dan keadilannya tetap terjaga. Oleh karena itu, agar sesuai dengan sifat ilmu hukum yang prespektif dan terapan, jenis penelitian yang digunakan dalam penelitian ini adalah metode penelitian hukum yuridis. Bahan Hukum Primer merupakan bahan-bahan hukum yang memiliki

\footnotetext{
${ }^{23}$ Keputusan Ketua Bapepam Nomor Kep-47/PM/1997 Peraturan Nomor VI.A.2
} 
kekuatan hukum mengikat, seperti peraturan perundang-undangan yang berlaku di Indonesia, yakni:

1. Undang-Undang No. 7 Tahun 1992 tentang Perbankan;

2. Undang-Undang No. 10 Tahun 1998 tentang Perubahan Atas UndangUndang No.7 Tahun 1992 tentang Perbankan;

3. Undang-Undang No. 8 Tahun 1995 tentang Pasar Modal;

4. Undang-Undang Republik Indonesia No. 29 Tahun 1999 tentang Bank Indonesia.

5. Peraturan Pemerintah Republik Indonesia No. 7 Tahun 2010 tentang Standar Akuntansi Pemerintah.

6. Peraturan Pemerintah Republik Indonesia No. 45 tahun 1995

4. tentang Penyelenggaraan Kegiatan di Bidang Pasar Modal

7. Peraturan Bank Indonesia No. 3/10/PBI/2001.

8. Peraturan Bank Indonesia No. 7/4/PBI/2005.

9. Peraturan Otoritas Jasa Keuangan No. X.G.2

10. Keputusan Ketua Bapepam No. Kep-47/PM/1997 Peraturan Nomor VI.A.2.

11. Keputusan Ketua Bapepam No. Kep-28/PM/1998 Peraturan Nomor V.D.4

Di dalam penelitian hukum terdapat beberapa pendekatan. Dengan pendekatan yang dipakai, peneliti akan mendapatkan informasi dari berbagai aspek mengenai isu yang sedang dibahas. Pendekatan yang dilakukan dalam penelitian ini adalah Pendekatan Undang-Undang dan Pendekatan Konseptual.

\section{Pembahasan}

Konsep pasar barang atau pasar tradisional yang telah dikenal umum oleh masyarakat dengan Pasar Modal tidak jauh berbeda, keduanya samasama merupakan sebuah tempat untuk memperdagangkan suatu objek oleh penjual dan kemudian dibeli oleh pembeli. Namun, yang membedakan terletak pada jenis-jenis produk yang diperdagangkan. Pada Pasar Modal 72 yang merupakan pasar yang bersifat abstrak, yang aktivitas transaksinya secara fisik hanya dapat 
dilihat di bursa (exchange) dan komoditi yang diperjual-belikan adalah suratsurat berharga jangka panjang yang keterkaitannya dalam investasi lebih dari satu tahun. Selain itu, proses transaksi yang terjadi antara pihak penjual dan pembeli dilakukan melalui perantara pedagang efek yang populer dengan sebutan "pialang". Perbedaan lainnya adalah, pembeli di Pasar Modal dapat memperoleh informasi mengenai barang yang akan dibeli melalui penglihatan secara langsung, maka pembeli di Pasar Modal dapat memperoleh informasi mengenai surat berharga yang dibelinya melalui prospektus ${ }^{24}$ atau kajian tentang surat berharga tertentu yang diterbitkan oleh para analis sekuritas. ${ }^{25}$

Sama halnya dengan pasar-pasar pada umumnya, Pasar Modal juga memiliki produk yang dijadikan objek perdagangan dalam bursa efek yang dikenal dengan sebutan Instrumen Pasar Modal. Instrumen Pasar Modal adalah semua surat berharga (efek) yang secara umum diperjualbelikan melalui Pasar Modal. Menurut Undang-Undang No. 8 Tahun 1995 tentang Pasar Modal, efek adalah setiap surat pengakuan utang, surat berharga komersial, saham, obligasi, sekuritas kredit, tanda bukti utang, setiap right, waran, opsi, atau derivatif dari efek, atau setiap insturmen yang ditetapkan sebagai efek. Umumnya, sekuritas yang diperdagangkan di pasar modal meliputi saham, obligasi, reksadana, dan instrument derivatif. ${ }^{26}$

Di dalam Pasar Modal terdapat Lembaga yang menjadi Penunjang Pasar Modal, yang salah satunya adalah Kustodian. Sesuai dengan yang tercantum dalam Pasal 43 Undang-Undang No. 8 Tahun 1995 tentang Pasar Modal, yang dapat menyelenggarakan kegiatan usaha sebagai Kustodian ialah Lembaga Penyimpanan dan Penyelesaian (LPP), atau Bank Umum yang telah mendapat

\footnotetext{
${ }^{24}$ Berdasarkan Pasal 1 angka 26 Undang-Undang No. 8 Tahun 1995, Prospektus adalah setiap informasi tertulis sehubungan dengan Penawaran Umum dengan tujuan agar Pihak lain membeli Efek

25 Ibid.

${ }^{26}$ Eduardus Tandelilin, Analisis Investasi dan Manajemen Portofolio, Edisi Pertama, BPFE, Yogyakarta, 2001, hlm. 18
} 
persetujuan Bapepam. Mengingat karena keberadaan pasal tersebut, maka dinilai merupakan suatu kewajiban bahwa setiap kegiatan Kustodian yang dilaksanakan oleh Bank Umum, maka Bank tersebut harus tetap melaksanakan prinsip-prinsip atau asas-asas yang telah menjadi landasan suatu Bank.

Dalam praktiknya, Bank selaku Kustodian dalam menerapkan prinsip kehati-hatian yang merupakan suatu asas yang menyatakan bahwa bank dalam menjalankan fungsi dan kegiatan usahanya wajib menerapkan prinsip kehatihatian dalam rangka melindungi dana masyarakat yang dipercayakan kepadanya. ${ }^{27}$ Sejalan dengan penerapan prinsip kehati-hatian tersebut, Bank selaku Kustodian juga menerapkan prinsip Know Your Customer atau Prinsip Mengenal Nasabah, yang dalam Peraturan Bank Indonesia No. 3/10/PBI/2001 memberikan definisi sebagai berikut, 28

\section{"Prinsip Mengenal Nasabah adalah prinsip yang diterapkan Bank untuk mengetahui identitas nasabah, memantau kegiatan transaksi nasabah termasuk pelaporan transaksi yang mencurigakan."}

Prinsip Know Your Customer atau Prinsip Mengenal Nasabah diterapkan dengan menggabungkan modifikasi hal-hal yang berkaitan dengan alasan atau dasar penggunaan Kustodian yakni sebagai pihak yang memberikan jasa penitipan Efek dan harta lain yang berkaitan dengan Efek serta jasa lain, termasuk menerima dividen, bunga, dan hak-hak lain, menyelesaikan transaksi efek dan juga mewakili pemegang rekening yang menjadi nasabahnya. ${ }^{29}$ Tujuan diterapkannya prinsip Know Your Customer adalah untuk mengetahui informasi terkait latar belakang customer yang ditangani oleh bank tersebut. Sedangkan diterapkannya prinsip kehati-hatian pada Bank selaku Kustodian adalah agar bank harus tetap menjaga agar kegiatan Kustodian tetap memperhatikan kemungkinan risiko yang akan timbul, tidak mengakibatkan risiko yang tidak

\footnotetext{
${ }^{27}$ Bellefroid, Pengertian Asas Pakar Hukum, Kencana Prenada Media Group, Jakarta, 2010, hlm. 14

28 Pasal 1 angka 2 Peraturan Bank Indonesia No. 3/10/PBI/2001

${ }^{29}$ Lihat Pasal 1 angka 8 Undang-Undang No. 8 Tahun 1995
} 
dapat dimitigasi, tidak mengakibatkan rasio kewajiban penyediaan modal minimum lebih rendah dari ketentuan yang berlaku, dan juga dengan diterapkannya prinsip kehatihatian tersebut dapat menjamin kesehatan bank sebagai Kustodian di Pasar Modal agar selalu baik sehingga para Nasabah akan dapat selalu menitipkan asetnya kepada Bank Kustodian.

Mengacu pada Undang-Undang Perbankan dan peraturan turunannya, telah dituliskan secara jelas mengenai kegiatan usaha Bank. Bahwa sejalan dengan pelaksanaan kegiatan usaha tersebut, dinilai perlu dan wajib untuk diterapkan asas-asas atau prinsip-prinsip yang menjadi landasan pelaksanaan kegiatan usaha Bank, yang salah satunya adalah prinsip kehatihatian. Sebagaimana disebutkan dalam Pasal 29 ayat (2) Undang-Undang No. 7 Tahun 1992 tentang Perbankan juncto Undang-Undang No. 10 Tahun 1998 tentang Perubahan Atas Undang-Undang No. 7 Tahun 1992 tentang Perbankan, yang menyebutkan,

"Bank wajib memelihara tingkat kesehatan bank sesuai dengan ketentuan kecukupan modal, kualitas aset, kualitas manajemen, likuiditas, rentabilitas, solvabilitas, dan aspek lain yang berhubungan dengan usaha bank, dan wajib melakukan kegiatan usaha sesuai dengan prinsip kehati-hatian."

Pasal 29 ayat (3), ayat (4), dan ayat (5) Undang-Undang No. 7 Tahun 1992 tentang Perbankan juncto Undang-Undang No. 10 Tahun 1998 tentang Perubahan Atas Undang-Undang No. 7 Tahun 1992 tentang Perbankan, pada pokoknya menerangkan dalam melaksanakan kegiatan usaha, bank wajib menempuh cara-cara yang tidak merugikan bank dan kepentingan nasabah yang mempercayakan dananya kepada bank. Demi kepentingan para nasabah, bank wajib menyediakan informasi mengenai kemungkinan timbulnya riisko kerugian sehubungan dengan transaksi nasabah yang dilakukan melalui bank. Hal-hal tersebut di atas telah ditetapkan oleh Bank Indonesia dan merupakan ketentuan wajib yang harus dipenuhi oleh bank. 
Jika dikaitkan dengan Undang-Undang No. 8 Tahun 1995 tentang Pasar Modal, sebagaimana tercantum dalam Pasal 43 ayat (1), yang menyatakan bahwa,
"Yang dapat menyelenggarakan kegiatan usaha sebagai Kustodian adalah Lembaga Penyimpanan dan Penyelesaian, Perusahaan Efek, atau Bank Umum yang telah mendapat persetujuan BAPEPAM."

Berdasarkan Pasal 43 ayat (1) tersebut dengan dikaitkan dengan UndangUndang Perbankan, dapat disimpulkan bahwa kegiatan penitipan adalah salah satu kegiatan Bank Umum sebagaimana dimaksud dalam peraturan perundangundangan di bidang perbankan. Oleh karena itu, Bank Umum tidak lagi memerlukan izin untuk melakukan kegiatan penitipan. Namun, untuk melakukan kegiatan sebagai Kustodian yang merupakan kegiatan yang lebih luas dari kegiatan penitipan dan terkait dengan kegiatan lembaga lainnya, maka Bank Umum tetap memerlukan persetujuan BAPEPAM. ${ }^{30}$ Yang berarti, dalam menjalankan kegiatannya sebagai Kustodian, pengaturan Bank Kustodian yang begitu jelasnya dalam Undang-Undang Pasar Modal, jika dikaitkan dengan pengaturan Perbankan, maka Bank Umum yang menjalankan kegiatan sebagai Kustodian tetap harus melaksanakan prinsip-prinsip dasarnya, termasuk prinsip kehatihatian.

Dalam menjalankan fungsinya sebagai tempat penyimpanan atau penitipan, Nasabah atau Investor menitipkan efeknya kepada Bank Kustodian, sebagai lanjutan dari kegiatan Bank Kustodian membuka rekening efek untuk Nasabahnya, Bank Kustodian selanjutnya membuka rekening efek pada LPP. Dalam konteks yang demikian, setiap lembar efek yang dimiliki oleh investor pemilik efek sepadan dengan satu dengan lainnya. Bagi, LPP, efek-efek yang pada Bank Kustodian tersebut adalah efek-efek yang secara kolektif dititipkan kepadanya, sebagai Lembaga penitipan kolektif tertinggi. Dalam hal apapun,

${ }^{30}$ Lihat Penjelasan Pasal 43 ayat (1) Undang-Undang No. 8 Tahun 1995 
sehubungan dengan penitipan, Bank Kustodian tidak dapat melakukan transaksi perdagangan efek melalui bursa efek. ${ }^{31}$

Fungsi lain yang terkait dengan penitipan pada Bank Kustodian ini adalah fungsi penitipan kolektif yang dapat terjadi sehubungan dengan Kustodian Sentral Efek Indonesia, Reksa Dana Perseroan, Manajer Investasi, serta para Investor, baik Reksa Dana Perseroan maupun ReksaDana KIK. ${ }^{32}$ Berdasarkan fungsi tersebut, bahwa tampak jelas bahwa Bank Kustodian, baik dalam perjanjian penitipan kolektif, maupun $\mathrm{KIK}$, bukanlah pemilik dari efek yang menjadi dasar penerbitan saham oleh Reksa Dana Perseroan atau penerbitan unit penyertaan oleh Reksa Dana KIK. Meski demikian, untuk melindungi kepentingan investor dan unit penyertaan, seluruh efek yang menjadi dasar bagi penerbitan saham dan unit penyertaan, kemudian dicatatkan atas nama Bank Kustodian dalam penitipan kolektif tersebut. Ini menjadikan seluruh investor pemegang saham dan unit penyertaan adalah beneficiary yang merupakan pemilik bersama yang terikat dari seluruh efek yang dijadikan sebagai the underlying asset yang merupakan trust corpus bagi seluruh investor pemegang saham atau pemegang unit penyertaan tersebut. 33

Kustodian yang menyelenggarakan kegiatan penitipan bertanggung jawab untuk menyimpan efek milik pemegang rekening dan memenuhi kewajiban lain sesuai dengan kontrak antara Kustodian dengan pemegang rekening tersebut. Efek yang dititipkan pada Kustodian wajib dibukukan dan dicatat secara tersendiri dan bukan merupakan bagian dari harta Kustodian tersebut. Kustodian hanya dapat mengeluarkan efek atau dana yang tercatat pada rekening efek atas perintah tertulis dari pemegang rekening atau pihak yang diberi wewenang untuk bertindak atas namanya. Apabila pemegang mengalami

\footnotetext{
${ }^{31}$ Gunawan Widjaja, Transplantasi Trusts dalam KUH Perdata, KUHD, dan Undang-Undang Pasar Modal Indonesia, PT RajaGrafindo Persada, Jakarta, 2008, hlm. 473.

32 Ibid., hlm. 474

33 Ibid.
} 
kerugian atas kesalahan pihak Kustodian, maka pihak Kustodian wajib memberikan ganti rugi kepada pemegang rekening tersebut. ${ }^{34}$

Adapun jasa yang diberikan Kustodian ialah sebagai berikut: 35

1. Menyediakan tempat penitipan harta yang aman bagi surat-surat berharga (efek);

2. Mencatat dan membukukan semua penitipan pihak lain secara cermat (jasa administrasi);

3. Mengamankan semua penerimaan dan penyerahan Efek untuk kepenitngan pihak yang diwakilinya;

4. Mengamankan pemindahtanganan Efek;

5. Menagih dividen saham, bunga obligasi dan hak-hak lain yang berkaitan dengan surat berharga yang dititipkan.

Dalam Peraturan Otoritas Jasa Keuangan No. X.G.2 telah diatur pemeliharaan dokumen tertentu oleh bank kustodian yang terkait dengan efek yang berada dalam simpanannya, yang secara detail diatur sebagai berikut: ${ }^{36}$

1. Setiap Bank Kustodian wajib mengadministrasikan, menyimpan, dan memelihara catatan, pembukuan, data, dan keterangan tertulis yang berhubungan dengan:
a. Nasabah yang efeknya disimpan pada Bank Kustodian,
b. Posisi efek yang disimpan pada Bank Kustodian,
c. Buku daftar nasabah dan administrasi penyimpanannya
d. serta hak nasabah yang melekat pada efek yang dititipkan, dan
e. Tempat penyimpanan yang aman dan terpisah.

2. Dokumen sebagaimana dimaksud dalam angka 1 huruf a peraturan ini sekurang-kurangnya terdiri dari:
a. Kontrak dengan nasabah jasa bank kustodian, dan
b. Daftar biaya untuk jasa-jasa yang diberikan.

\footnotetext{
${ }^{34}$ Doli Hanafi Siregar, Tinjauan Yuridis Bank Sebagai Kustodian dalam Penyelenggaraan Reksa Dana (Studi Kasus Citibank Cabang Medan), (Medan, Universitas Sumatera Utara, 2009), hlm. 60

${ }^{35}$ Ibid., hlm. 61

36 Ibid., hlm. 184
} 
c. Dokumen sebagaimana dimaksud dalam angka 1 huruf b peraturan ini terdiri dari sekurang-kurangnya:

d. Status efek nasabah yang disimpan,

e. Rahasia efek yang disimpan,

f. Bentuk efek sebagai sertifikat atau bukti penitipan kolektif lainnya.

3. Dokumen sebagaimana dimaksud dalam angka 1 huruf c peraturan ini sekurang-kurangnya memuat:

a. Daftar transaksi harian efek,

b. Pembagian dividen, bonus, pelaksanaan hak memesan efek terlebih dahulu atau hak atas efek lainnya, termasuk penggunaan hak suara yang diwakilkan,

c. Memorandum penyelesaian perselisihan antar nasabah, BAE, dan anggota bursa.

4. Dokumen sebagaimana dimaksud dalam angka 1 huruf $d$ peraturan ini sekurang-kurangnya memuat:

a. Pegawai yang khusus bertanggung jawab atas pengoperasian jasa kustodian,

b. Perubahan penanggung jawab bank kustodian,

c. Spesifikasi ruangan penyimpanan efek, lemari besi, atau brankas, dan

d. Buku pedoman operasional.

5. Dokumen sebagaimana dimaksud dalam angka 1, angka 2, angka 3, angka 4, angka 5, peraturan ini wajib disimpan di tempat yang aman dan terpisah dari kegiatan bank lainnya dan wajib tersedia setiap saat untuk kepentingan pemeriksaan Otoritas Jasa Keuangan (OJK).

6. Dokumen-dokumen sebagaimana dimaksud dalam angka 6 peraturan ini wajib disimpan sekurang-kurangnya untuk masa 5 (lima) tahun.

Dalam ketentuan tersebut di atas jelas ditunjukkan bahwa dala suatu penitipan pada Bank Kustodian oleh Nasabahnya, Bank Kustodian diwajibkan 
untuk tetap mengemukakan dengan jelas identitas dari nasabah yang efeknya disimpan oleh Bank Kustodian tersebut. Jadi dalam hal ini tidak ada atau tidak mungkin lagi adanya rahasia yang disembunyikan baik mengenai Nasabah pemilik efek yang sebenarnya dan efek yang berada dalam pemilik efek yang sebenarnya dan efek yang berada dalam penyimpanan Bank Kustodian tersebut. ${ }^{37}$

Kegiatan Bank selaku Kustodian, pada praktiknya telah sesuai berdasarkan Petunjuk Pelaksanaan Peraturan Pasar Modal, Bank Kustodian wajib melaksanakan Penitipan Kolektif dan penyimpanan atas seluruh dokumen berharga berkaitan dengan Kontrak Investasi Kolektif Efek Beragun Aset, melaksanakan penyimpanan dana yang merupakan asset keuangan dalam portofolio Kontrak Investasi Kolektif Efek Beragun Aset, menyerahkan dan menerima aset keuangan untuk kepentingan Kontrak Investasi Kolektif Efek Beragun Aset, melakukan pembayaran semua transaksi atas perintah Manajer Investasi yang berkaitan dengan Kontrak Investasi Kolektif Efek Beragun Aset, mendaftarkan atas nama Bank Kustodian aset keuangan dalam portofolio Kontrak Investasi Kolektif Efek Beragun Aset sebagai wakil dari pemegang Efek Beragun Aset, melaksanakan pembukuan atas hal-hal yang berkaitan dengan Kontrak Investasi Kolektif Efek Beragun Aset, membuat dan menyimpan daftar pemegang Efek Beragun Aset dan mencatat perpindahan kepemilikan Efek Beragun Aset atau menunjuk BAE untuk melakukan jasa tersebut berdasarkan persetujuan dari Manajer Investasi, memisahkan aset keuangan Kontrak Investasi Kolektif Efek Beragun Aset dari aset keuangan Bank Kustodian dan atau kekayaan nasabah lain dari Bank Kustodian, melaporkan secara tertulis kepada BAPEPAM apabila Manajer Investasi melakukan kegiatan yang dapat merugikan pemegang Efek Beragun Aset selambat-lambatnya akhir hari kerja berikutnya, dan melaksanakan tugas lain yang berkaitan dengan portofolio

${ }^{37}$ Ibid., hlm. 185 
Kontrak Investasi Kolektif Efek Beragun Aset sebagaimana ditentukan dalam Kontrak Investasi Kolektif. ${ }^{38}$

Dengan penerapan kegiatan Kustodian yang sesuai dengan pengaturannya akan mencapai tujuan Pasar Modal Indonesia yang menjadi induk dari Kustodian yakni adalah sebagai berikut: ${ }^{39}$

1. Sebagai fasilitas melakukan interaksi antara pembeli dengan penjual untuk menentukan harga saham atau surat berharga yang diperjualbelikan.

2. Memberikan kesempatan kepada para pemodal untuk menentukan hasil (return) yang diharapkan.

3. Memberikan kesempatan kepada investor untuk menjual kembali saham yang dimilikinya atau surat berharga lainnya.

4. Menciptakan kesempatan kepada masyarakat untuk berpartisipasi dalam perkembangan suatu perekonomian.

5. Mengurangi biaya informasi dan transaksi surat berharga.

\section{Kesimpulan}

Mengenai penerapan prinsip kehati-hatian pada bank selaku custodian dalam bidang Pasar Modal di Indonesia dapat dinilai telah sesuai dengan peraturan perundang-undangan yang berlaku, karena pada dasarnya semuanya telah diatur baik dalam Undang-Undang No. 8 Tahun 1995 tentang Pasar Modal maupun Undang-Undang No. 8 Tahun 1995 tentang Pasar Modal dan UndangUndang No. 7 Tahun 1992 tentang Perbankan juncto Undang-Undang No. 10 Tahun 1998 tentang Perubahan Atas Undang-Undang No. 7 Tahun 1992 tentang Perbankan. Meskipun hal-hal tersebut telah dinyatakan secara jelas dalam Undang-Undang Perbankan, namun bagaimana tata cara penerapan prinsip kehati-hatian pada Bank selaku Kustodian tidak dinyatakan secara jelas baik dalam Undang-Undang Perbankan maupun dalam turunannya. Kurangnya

\footnotetext{
${ }^{38}$ Keputusan Ketua BAPEPAM Nomor Kep-47/PM/1997 Peraturan Nomor VI.A.2

${ }^{39}$ Sunariyah, Pengantar Pengetahuan Pasar Modal, Edisi Kelima, UPP STIM YKPN, Yogyakarta, 2006, hlm. 7
} 
kejelasan pengaturan prinsip kehati-hatian pada Bank selaku Kustodian dapat menyebabkan ketidakpastian bagi para pembaca undang-undang.

\section{Daftar Pustaka}

Buku

Anwar, Jusuf. Pasar Modal Sebagai Sarana Pembiayaan dan Investasi. Bandung: PT Alumni Bandung. 2010

Bellefroid. Pengertian Asas Pakar Hukum. Jakarta: Kencana Prenada Media Group. 2010

Hartono, Sunaryati. Politik Hukum Menuju Satu Sistem Hukum Nasional. Bandung: PT Alumni. 2000

Mustafa, Bachsan. Sistem Hukum Indonesia Terpadu. Bandung: Citra Aditya Bakti. 2003

Rahardjo, Satjipto. Hukum dan Masyarakat. Bandung: Penerbit Angkasa. 1980

Rasjidi, Lili dan IB. Wyasa Putra. Hukum sebagai Suatu Sistem. Bandung: Penerbit Mandar Maju. 2003

Reed, Edward W. dan Edward K. Gill. Commercial Bank. Jakarta: Prentice, Hall Inc., Bumi Aksara. 1995

Sihombing, Jonker. Investasi Asing Melalui Surat Utang Negara di Pasar Modal. Bandung: PT Alumni. 2013

Sudaryo, Yoyo dan Aditya Yudanegara. Investasi Bank dan Lembaga Keuangan. Yogyakarta: CV. Andi Offset. 2017

Tandelilin, Eduardus. Analisis Investasi dan Manajemen Portofolio. Edisi Pertama. Yogyakarta: BPFE. 2001

Zaini, Zulfi Diane. Independensi Bank Indonesia dan Penyelesaian Bank Bermasalah. Bandung: Keni Media. 2012

Jurnal Hukum

Chuppe, Terry M. dan Michael Atkins. Regulation of Securities Markets Some Rescue Trend and Their Implications for Emerging Markets. Washington DC-USA: Policy Research Working Paper, The World Bank. 1992 
P-ISSN: 2656-534X, E-ISSN: 2656-5358

Jurnal Suara Hukum, Vol. 2, No. 1, Maret 2020

Pardy, Robert. Institutional Reform in Emerging Securities Markets. Washington DC, USA: The World Bank. 1992

Soepraptomo, Heri. Analisis Ekonomi Terhadap Hukum Perbankan. Jakarta:

Makalah pada Pertemuan Ilmiah tentang Analisis Ekonomi terhadap Hukum dalam Menyongsong Era Globalisasi. BPHN - Departemen Kehakiman. 10-11 Desember. 1996 